\title{
An Analysis on Students' Speaking Ability of Procedure Text at Senior High School
}

\author{
Karina Kurnia Marbes ${ }^{1]}$, Andi Idayani ${ }^{2]}$ \\ Universitas Islam Riau \\ E-mail: ${ }^{1}$ karinakurniam16@ gmail.com, \\ ${ }^{2]}$ andiidayani@edu.uir.ac.id
}

\begin{abstract}
This research discusses the students' speaking ability of Procedure Text at the Second Grade Students of SMA Tri Bhakti Pekanbaru. The objective of the research is to know the students' speaking ability in procedure text and to find out which aspectt is the most dominant problem for the students in speaking. The design of this research was qualitative research. The result of data was students' comprehension score was 3.15 because most of them understood the directions on the speaking test well and they also conveyed the procedure text sequentially using the simple present tense correctly so that the listener could understand them although there were several problems. Students' fluency score was 3.15 because most of the students' present the procedure text fluently and smoothly even though some students stammered and paused several times. Students' grammar score was 3.13 because most of them were good at arranging their sentences correctly according to the grammar rules using the simple present tense even though they made some mistakes. The students' pronunciation score was 2.86 because some students had difficulty in pronouncing some words and there were some confusions with the listener, although not all students did so. Students' vocabulary score was 2.92 because some students had problem with vocabulary mastery and use inappropriate vocabulary, but overall the students have sufficient vocabulary to express tips simply related to the topic. In conclusion, the students' speaking ability on procedure text is in a good category.
\end{abstract}

Keywords: Procedure text, speaking ability, senior high school

\section{Analisis Kemampuan Berbicara Siswa pada Teks Prosedur di Sekolah Menegah Atas}

\begin{abstract}
Abstrak
Penelitian ini membahas tentang kemampuan berbicara siswa dalam Procedure Text pada Siswa Kelas Dua SMA Tri Bhakti Pekanbaru. Tujuan dari penelitian ini adalah untuk mengetahui kemampuan berbicara siswa dalam teks prosedur dan untuk mengetahui aspek mana yang merupakan masalah yang paling dominan bagi siswa dalam berbicara. Desain penelitian ini menggunakan penelitian kualitatif. Hasil analisis data skor pemahaman siswa adalah 3.15 karena sebagian besar siswa memahami arahan pada tes berbicara dengan baik dan mereka juga menyampaikan teks prosedur secara berurutan menggunakan simple present tense dengan benar sehingga pendengar dapat memahaminya meskipun ada beberapa masalah. Nilai
\end{abstract}


kefasihan siswa adalah 3.15 karena sebagian besar siswa menyajikan teks prosedur dengan lancar dan lancar meskipun beberapa siswa tergagap dan berhenti beberapa kali. Nilai grammar siswa adalah 3.13 karena sebagian besar dari mereka pandai mengatur kalimat mereka dengan benar sesuai dengan aturan tata bahasa menggunakan simple present tense meskipun mereka membuat beberapa kesalahan. Skor pengucapan siswa adalah 2.86 karena beberapa siswa mengalami kesulitan mengucapkan beberapa kata dan ada beberapa kebingungan dengan pendengar, meskipun tidak semua siswa melakukannya. Nilai kosakata siswa adalah 2.92 karena beberapa siswa memiliki masalah dengan penguasaan kosakata dan penggunaan kosakata yang tidak tepat, tetapi secara keseluruhan siswa memiliki kosakata yang cukup untuk mengungkapkan kiat-kiat yang hanya berhubungan dengan topik. Kesimpulannya, kemampuan berbicara siswa pada teks prosedur berada pada kategori baik.

Kata Kunci: Teks prosedur, kemampuan berbicara, sekolah menengah atas

\section{INTRODUCTION}

Nowadays English is essential to be mastered for people because it has several benefits in major fields such as business, tourism, education and technology. With the advent of globalisation, people working in those sectors have no choice but to master English communication skills in order to be successful in their jobs. Therefore, teachers need to help their students improve their English communication skills to prepare for their future careers.

Indonesia, speaking is an important aspect of foreign language learning and instruction. Speaking becomes an important thing that must be learned by English learners in Indonesia because How people convey their views is determined by their capacity to speak or communicate with others, opinions, feelings, and ideas each other. Therefore speaking ability takes an important role in learning foreign languages.

Both English teacher and students teach and learning speaking just as a repetition of drill. Speaking is one of fundamental and demanding skill to be mastered by English learners. When people have good ability in speaking, People may express themselves and learn how to follow the relevant social and cultural rules in any communicative situation. During the learning process at Education Institution of Teacher, many students have low speaking ability. They do not respond the learning process in the class. They as teacher candidates are expected to speak effectively (Darmuki et al, 2017)

On the latest curriculum, Students are expected to have solid speaking skills, according to the 2013 curriculum. However, speaking is not as simple as we may believe. It is a complicated skill that needs processes because many aspects should be considered like vocabulary, grammar, fluency, pronunciation and comprehension. As stated by Idayani (2019) that Speaking is peaking is characterize as an collective process of building up meaning that involves producing, receiving and processing information.

A person's speaking skill is normally assessed through a real-time face-to-face encounter between an interlocutor and the candidate. In speaking, there are several aspects in it, namely grammar, vocabulary, pronunciation, accuracy and fluency. Therefore, all the aspects will help the 
speakers in communicating in English. The reality is many students find difficulties in speaking aspects in English language learning. When the teacher asked them to speak, they get trouble.

Based on the researcher's observation of procedure text in second year students of SMA Tri Bhakti, it showed that there were many students had difficulties in procedure text especially in speaking. It was proven by the students' low speaking ability. They had no motivation to speak in English. The first problem was students cannot speak fluently because they didn't have self-confidence to speak in front of the class. When the teacher asked the students by using English, most of them just smiled and didn't answer. Some students tried to answer using English but not fluent. This phenomenon happened because the students were shy with their friend and afraid to make mistakes.

The second was they had incorrect pronunciation. It because they seldom to practice their English. The students were often wrongly pronounced and then corrected by the teacher. They needed to pronounce the words repeatedly to make it right. The students didn't care about the pronunciation. When the teacher asked them to bring a dictionary during English lessons to see how to pronounce the words, they often didn't carry it.

The next problem was the students had lack of vocabulary mastery and lack understanding of grammatical. The students didn't know appropriate words that can be used when they try to speak. Besides, the students had difficulty making sentences with the correct structure.

The writer recognized certain issues based on the backdrop of the problem and various phenomena that the researcher discovered regarding students' difficulties in procedural text. Firstly, the students could not speak English fluently yet, because they did not have selfconfidence to speak in the class. They had difficulties in expressing ideas and opinions orally as they were afraid of making mistakes. They decided to be quite or stop to speak in the middle of explanation just because they did not know what to say. It makes the points of the students' explanation could not be delivered clearly.

From the classroom observation during the learning activities, the students were very shy to speak English in class with friends or with the teacher. In addition, most of them were reluctant to express their opinions in English as they were afraid of making mistakes when speaking in front of the class as well as being compared to other students. A number of students in the course reported that they understood what the teacher asked; however, they did not want to volunteer to answer the questions as some of their classmates might think that they want to show off. Moreover, they were not sure if they used English correctly as they also lacked vocabulary and grammar.

The aim of the research is to know the second grade of SMA Tri Bhakti students' speaking ability and to find out which aspectst is the most difficult for the second grade students of SMA Tri Bhakti in speaking.

Speaking is one of the skills that of English language; it is as a skill that needs more attention from the students, because the students should have good interaction each other in speaking as human being. Some experts have various definitions about speaking.

Brown and Yule (2012) proposed speaking as the ability to pronounce language sounds to express or convey thought, ideas, and feeling orally. In line with the above opinion, Nurgiantoro 
(2011) argued that speaking is the second language activity done by human after listening. According to Idayani (2019) speaking is complex skill because when we communicate to others, we need to catch a special end which can be expressing our ideas, wishes, solving and negotiating problems or establishing and maintaining social relationships and friendships.

There are at least five factors to examine when evaluating speaking ability that are commonly used as benchmarks. Grammar, fluency, understanding, pronunciation, and vocabulary are the four components.

\section{Grammar}

Grammar, according to Cowan (2008), is a collection of rules that specifies how words and groups of words may be ordered to produce sentences in a given language. It must be taught using a language structure system. Learners must be taught about word order, inflection, and derivation, as well as other important aspects of the English language. It will assist pupils in constructing a good phrase and speaking smoothly in conversation.

\section{Vocabulary}

According to Ur (2012), vocabulary has a crucial part in enhancing speaking ability. It is concerned with the proper and suitable use of words. The words in a language can be generally characterized as vocabulary. Every language in the words has its unique set of words. People who lack a significant vocabulary will be unable to communicate effectively or explain their ideas.

\section{Fluency}

Fluency is defined as the capacity to communicate in a communicative, accurate, and fluent manner. Fluency refers to the ability to speak fluently and without interruption. Fluency signals are defined as suitable speed and ease of speaking without disrupting the flow of conversation (Newton \& Nation, 2021). In other words, simply a few pauses, such as uh, ah, and er.

\section{Pronunciation}

The way we produce the sound of words or how a language is pronounced is referred to as pronounciation. It is connected to the phonological process, which refers to the elements and rules of a grammar that define how sound patterns vary in language. Pronunciation, one of the speech activities that needs cognitive control in pronouncing words, which is an important part of speaking (Chan, n.d , 2018.)

\section{Comprehension}

The study of how well kids grasp the language is known as comprehension. Comprehension, is the ability to act effectively based on affordances connected to the body, the physical world, personal aspirations, and cultural norms (Glenberg, 2011).

Teaching speaking implies teaching how to use language for communication, for transferring thought, ideas or feeling to other people. The purpose of teaching speaking is to be able to communicate efficiently. Besides, the students should be able to avoid confusion in the message that they want to deliver due to faulty pronunciation, grammar or vocabulary.

According to Pawlak and Waniek-Klimczak (2015) at any level, teaching speaking is an important part of improving students' sociolinguistic competence in a foreign language. Aside from the responsibility of parents at home in developing children' speaking abilities, instructors in schools are also 
obligated to educate pupils how to have effective speaking skills.

Wrench et al (2012) stated that speaking has three important purposes, there were:

\section{a. To inform}

Speaking is used by the speaker inform to the listener about anything they want or they need. This is about helping the listener acquire information that they do not already possess then use the information to understand something.

b. To persuade

People uses speaking to persuade the listener to do something in a certain activity. When we speak to persuade, we attempt to get listeners to embrace a point of view.

c. To entertain

Entertain speaking are very common in everyday life. The fundamental goal of an entertainment is listener's enjoyment, which can come in a variety of forms. Through speaking, people can express their feeling both sad and happy. If needed, someone can entertain her or him.

There are many classroom speaking activities that provide students with opportunities to practice their speaking skills both inside and outside of the classroom, assist them in becoming more socialized and active participants in the teaching learning process, and make learning more meaningful and enjoyable. There are some activities to promote speaking, which are "Picture Narrating", this activity is based on several sequential pictures. Students are asked to tell the story taking place in the sequential pictures by paying attention to the criteria provided by the teacher as a rubric. Rubrics can include the vocabulary or structures they need to use while narrating.
According to Dirgeyasa (2016), a procedure text is a document that is intended to convey how something is accomplished through a series of acts or stages. In a nutshell, procedure text is language that describes the steps involved in manufacturing or performing anything. It explains how individuals carry out various operations in a sequential order. This work often employs imperative phrases in the simple present tense.

Djatmika \& Pambudi (2015) state, procedure text is one type of text in English that shows and explains how to produce something according to a series of actions and regular steps. It contains some procedures, instructions, processes, and steps.

Procedure text is one of the texts in genre-based approach. In this research, procedure text is a piece of writing that tells us in formation of making or doing something through several steps or directions. The example of procedure texts includes cooking recipes, direction to find a place, rules game, manual instruction sofa tool, science experiment. However, the procedural texts that are used in this research are cooking recipes and manual steps of doing something (Ameliah et al., 2019)

Procedural texts are frequent factual genres that give step-by-step instructions on how to complete a task. Students encounter procedural texts in a variety of settings, including their homes (recipes), science (experiments), and technology (how to...), and other educational activities. The objective of procedural texts is to give sequenced information or directions so that individuals may safely, efficiently, and appropriately undertake activities. (Prihatna \& Him'mawan, 2015).

Every type of literature serves a societal purpose. One of the most significant aspects of a book is its social 
function. The text's goal or major theme is linked to the social function. Procedure text, like other forms of literature, has a societal purpose. The social role of procedural text, according to Napitupulu and Kisno (2014), is to provide directions for manufacturing or doing something for instance, directions, recipes, instructions, and manuals.

Furthermore, each text has a societal purpose. The text's elements must be understood by the students. A text is incomplete without a generic structure since the generic structure is the unique feature that distinguishes one genre from another. The structure of a text is a tool that aids communication. A process text's basic structure is as follows:

1. An introduction statement that states the purpose or goal of the project. This might be the text's title or the first paragraph.

2. A list of the materials required to conduct the process. This might be a paragraph or a list. In certain methods, this stage may be skipped.

3. A list of steps in the order in which they must be completed. In most cases, the sequence is crucial; terms like now, next, and after this can be utilized. The stages usually start with a command like add, stir, or push.

In forming a text, the steps or processing are needed to achieve it. Writing procedure text has a generic structure which should be done by the writer. They are as the following:

a. Title/Goal This shows the readers about the targets that must be achieved after following the flow of information which is packaged in a procedure text. This has an optional character which is created as an introductory sentence at the beginning of a word.

b. List/Material Material in the procedure text serves to explain the materials or equipment needed and used in related activities. It often gives detail on the size, color, numbers, shapes, quantity, etc.

c. Steps/Method/Procedure It describes steps in a logical order to achieve the goal. The steps are often marked with a number $[1,2,3 \ldots]$, letter $[\mathrm{a}$, b, c...], or bullet marks [,-,],sometimes the steps include caution [s] or warning [s]. There can also be drawings or pictures to make the steps clearer.

Furthermore, some researches about problem in speaking have be conducted by some researchers. For example at Second Grade SMP 8 Rambah Hilir by Siti Surinah Harahap in 2015. The result is the second grade students of SMP 8 Rambah Hilir district year 2014/2015 in speaking were good in speaking.

The second previous study, the researcher took by Anita Rinanda (2017) that investigated speaking ability of the second year students at MTs Hasanah Pekanbaru.The result showed that the students' speaking ability of the second year students at MTs Hasanah Pekanbaru was fair. The last research is conducted at XI Grade of Social Sciences 2 of SMAN 1 Kampar by Resi Rahmanis in 2019. The result is the XI Social Sciences 2 students' speaking skill of procedure text was low.

Although the three relevant studies above examine students' speaking abilities just like what the researcher examined as well, there were some differences in their studies with this research, that was the researcher investigated the speaking abilities of second grade students and focus on one subject, namely procedure text. In addition, the researcher used five aspects of speaking as a category for evaluating students' speaking abilities. Another thing that distinguishes this research was the 
activity that the researcher used in assessing students' speaking abilities of procedure text. In this study, the researcher used one of the speaking activities, namely picture narrating.

\section{METHOD}

This research was classified as descriptive qualitative design. Descriptive qualitative research is a kind of research concerning with acquiring data in the field which does not need use number (statistical analysis). According to Creswell (2012), qualitative research is a means for exploring and understanding the meaning individuals or groups ascribe to a social human problem. The process of research involves emerging questions and procedures; collecting data in the participants setting; analysing the data inductively, building from particulars to general themes; and making interpretations of the meaning of data. The final written report has a flexible writing structure.

There is only one variable in this study: speaking ability. The researcher followed five aspects as indicators of this research; grammar, vocabulary, fluency, pronunciation and comprehension. The reason why the researcher was conducted the research at SMA Tri Bhakti Pekanbaru because the researcher was interested to know the students' speaking ability in procedure text.

According to Sugiyono (2017), the population is a generalization area consisting of objects or things with certain features and characteristics that researchers choose to study and draw conclusions from. The population of the research were the second year students of SMA Tri Bhakti Pekanbaru in the Academic Year of 2019-2020. There were three classes of second grade students. It was consists of 90 students. In determining sample of this research, the researcher used Cluster Random sampling. As stated by Arifin in Jaenudin (2014) Cluster Random sampling is a sampling method based on a group of individuals and not taken individually. Based on classes that already exist the researcher used lottery and XI. IPA was selected as sample of the research. The number of students was 31 students. The reason used a cluster random sampling by using the whole Class XI IPA students in this study were to get accurate data. The researcher wanted to provide equal opportunities for every student in the class that chosen to be the sample.

Research instrument in this research was speaking test in procedure text. It was used to know students' speaking ability especially on grammar, vocabulary, comprehension, fluency and pronunciation. Researcher gave three topics to the students; they were tips to speak English fluently, tips to enhance English vocabulary and tips to do the homework faster. In order to obtain the data for this study, as the researcher, went through the following steps: The researcher presented three themes to the students, each with sequential photos and auxiliary sentences that connect to the method text, and asked them to pick one. The researcher then recorded all of the students' performances and transcribed the data into a script. The researcher next asked raters 1 and 2 to score students' speech using a speaking scoring rubric.

Following the data collection, the researcher transcribed each recorded student's speech one by one. When all transcripts were completed, the researcher enlisted the assistance of two raters in evaluating and scoring the student's proficiency with procedural text. Following that, the researcher categorized the pupils' speaking ability. Finally, the researcher looked at the students' ability to talk. The information gathered was examined using qualitative description. The researcher utilized the 
following oral proficiency rating categories criteria to examine the data.

\section{FINDING AND DISCUSSION Data Presentation}

This research was conducted to find out students' speaking ability at SMA Tri Bhakti Pekanbaru. The researcher provides the conclusions based on the data collected from the raters in this chapter. The researcher came against various difficulties in collecting data for this study, such as not being able to acquire all of the student data. Due to the Covid-19 epidemic, the teaching and learning method in schools was substituted with online learning.

As a result, even though they had been contacted repeatedly, some students refused to take the speaking exam for a variety of reasons, including unsupported devices, lack of data packages, and a lack of time due to other school obligations stacking up. As a result, the researcher was able to gather and evaluate data from 26 children from a total of 31 SMA Tri Bhakti Pekanbaru second grade students.

\section{The Result of Data}

The speaking ability of the second grade students at SMA Tri Bhakti Pekanbaru about procedure text can be seen from the scores they have obtained. From 26 of data sources, the researcher have collected and analysed by using scoring rubrics of speaking.

Table 1. Students' score in speaking of procedure text

\begin{tabular}{lccc}
\hline No & $\begin{array}{c}\text { Number } \\
\text { of } \\
\text { Students }\end{array}$ & Score & Category \\
\hline $\mathbf{1}$ & 3 & $\begin{array}{c}4.2- \\
5.0\end{array}$ & Excellent \\
$\mathbf{2}$ & 9 & $3.4-$ & Very Good
\end{tabular}

Total 26

Based on the Table 1, it can be shown 3 students got score of $4.2-5.0$ categorized excellent, 9 students got score $3.4-4.1$ categorized very good, 8 students got score $2.6-3.3$ categorized good, 4 students got score $1.8-2.5$ categorized poor and 2 students got score $1.0-1.7$ categorized very poor. Finally, we can conclude that most of students got very good categorize in performing procedure text.

The students' speaking ability of procedure text based on five components of speaking can be seen in the Figure 1 .

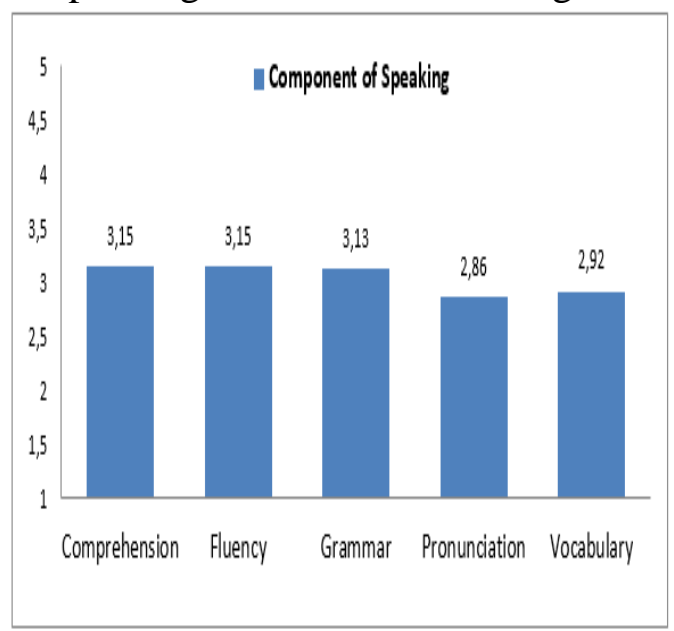

Figure 1. Students' speaking ability of procedure text for each component

From the Figure 1, it can be seen that the first component in speaking is the student's ability in Comprehension with the average score is 3.15.Comprehension 
is a speaking component with the highest average score that was collected from 26 students. In this research, the researcher found that overall; the students' comprehension ability was good. They were able to understand the directions on the speaking test well. Besides that, they also conveyed the procedure text sequentially using the simple present tense correctly so that the listener could understand them.

However, there are a few students had difficulties to thoroughly understand what is asked for on the speaking test and also about the tips on their chosen topic. There are some students who do not understand the rules or orders contained on the speaking test sheet. In the speaking test, students are asked to choose one of the topics then pay attention to and understand the sequential pictures that have been provided, and then present them in order within 1-2 minutes.

The fact is a few students do not understand the instructions given. For example, there are students who present tips that are not in the order and their performance is more than the allocated time. There are also students who do not understand the topic they choose or what is commonly called miscommunication. For example on the topic of "How To Do Homework Faster", the student thought that the homework in speaking test sheet was cleaning the house, even though what the speaking test meant was school assignments that had to be done at home. But overall, they were good in comprehension because most of the students understand what the speaking test asked them, and understood about their respective topics.

The second component in speaking based on the graphic above is the students' ability in Fluency with the average score is also 3.15. Fluency is the other component with the highest average score similar to comprehension that was collected from 26 students beside comprehension. For fluency, the researcher found that most of students' fluency is good. They able to present procedure text fluently and smoothly at normal speed, therefore it seem that they have mastered their topic. Even though, some students also have difficulties in fluency. They were stammered and paused several times, either long or short pauses in their speaking performance. They also repeated some words and said a few words like "aa", "eh", "mm" or "ee" while thinking about the next sentence they would say. This is usually happen because they rarely use English in their daily life or conversations. Their unfamiliarity makes them nervous and stammering in using the language.

Besides, they feel anxiety and unconfident in speaking. These things affect their fluency in speaking. Consequently, their speaking performance takes a lot of time so that their speaking is more than the stipulated time which is a maximum of 2 minutes. But, those mistakes were only happen to some of them, no to all of the students. In conclusion, their fluency is good for a reason that most of them able to speak fluently at normal speed.

As we can see, the third component in speaking is the students' ability in Grammar with the average score is a little bit lower than two previous components mentioned above. The score is 3.13. In the speaking test which is about procedure text, the tenses should be the simple present tense. The good thing is most of the students were good at arranging their sentences correctly according to the grammar rules using the simple present tense. Nonetheless, the researcher still found a student that used simple past tense in her speaking performance. But that wasn't a 
big deal because other than that one person knew they had to use the simple present tense and had no problems. They were also able to use conjunctions appropriately to link sentences and paragraphs. Then, the researcher notices that some students have another problem in grammar beside tenses, those are the students have difficulties creating correct sentences according to the grammar rules. Errors in grammar that the researcher found in the students' speaking test are: the students add the letter "s" behind a noun that is a singular, not a plural, and vice versa.

Moreover, some students have some difficulties in how to put conjunctions correctly between sentences or paragraph. A few students also use incorrect to be, and also forget that the verb "try" is followed by an infinitive, but those were not a hefty problem because the listener still can understand clearly what the students presented. To conclude, most of the students have good ability in grammar. They are able to use simple present tense correctly and their sentences also conform to the grammar rules.

Next, according to the figure above, the fourth component of speaking is Pronunciation and it is an aspect with dominant problem than the other components. The figure shows that the average score is 2.86 which are the lowest average score in the speaking component of the second grade students of SMA Tri Bhakti Pekanbaru. The researcher found that students had difficulties to pronounce some words, especially vocabularies that consist of several syllables and also words that they rarely heard. The result of the mispronunciation made by students is the listener should more concentration to hear what the students said.

Sometimes it ends up being miscommunication. Pronunciation errors usually occur because students only frequently use their mother tongue or first language. Therefore they are not accustomed to pronouncing the word in English correctly. Besides that, they also rarely see and hear how to pronounce the words correctly in dictionary or English pronunciation applications. Luckily, the mistakes in pronunciation were not made by all of students. Some of them also have good ability to pronounce words correctly. To sum up, the students pronunciation were good considering most of the students can pronounce the words correctly and can be understood by the listener.

Last, the figure above shows the last component of speaking is Vocabulary with the average score is 2.92 which is a little bit higher than pronunciation component score. Some problems that researcher found in students' vocabulary were some students seem to had problem with vocabulary mastery. They sometimes used wrong word choice, mumbled, and stopped talking when they perform their speaking test because their vocabulary is not broad. Furthermore, some of students usually match the meaning from what they have found in dictionary with word in a sentence without considering the word in its context. The use of inappropriate vocabulary affects the meaning therefore it is not in accordance with the context anymore. But overall, the students have sufficient vocabulary to express tips simply relate to the topic and the context even though the vocabulary is familiar or commonly used in everyday life.

To sum up, the mean score of the second grade students' speaking ability in performing procedure text is 3.03. It means the speaking ability of second grade students at SMA Tri Bhakti Pekanbaru is "good" and pronunciation is the most difficult aspect for the students. 


\section{CONCLUSION}

The research focused on students' speaking ability. Firstly, according to component of speaking ability, students' comprehension score is 3.15 as a result that the students' ability on comprehension is good. Secondly, students' fluency score is 3.15 because of overall students' ability on fluency are great for a reason that most of them do a fluent speech even though there are several pauses either long or short pauses.

Thirdly, students' grammar score is 3.13. Fourthly, students' pronunciation score is 2.86. Lastly, students' vocabulary score is 2.92 as a result of on the whole students' vocabulary is broad enough. From the explanation above, the researchers conclude that the students' speaking ability to present procedure text is in level 3. It means the students' speaking ability of procedure text at the second grade students of SMA Tri Bhakti Pekanbaru is good and the most difficult aspect for the students is pronunciation.

\section{REFERENCES}

Ameliah, M., Syam, U. K., Anugrawati, N., Sangkala, I., \& Abdul, N. B. (2019). Using Picture Media To Enhance Writing Ability in Procedure Text. Exposure Journal 48 English Education Department, 8(1), $\quad$ 48-59. https://doi.org/10.26618/exposure.v $8 \mathrm{i} 1.2072$

Brown G. \& G. Yule. (2012). Teaching the Spoken Language. London: Cambridge University Press.

Chan, M. J. (2018). Embodied Pronunciation Learning: Research and Practice. The Catesol Journal, 30(1), 47-68. http://ezproxy.lib.uconn.edu/login?u $\mathrm{rl}=\mathrm{https}: / /$ search.ebscohost.com/logi $\mathrm{n} . \operatorname{aspx}$ ?direct $=$ true $\& \mathrm{db}=$ eric $\& \mathrm{AN}=\mathrm{E}$
$\mathrm{J} 1174234$ \&site $=$ ehost-live

Creswell, J.W. (2012). Educational RESEARCH: Planning, Conducting, and Evaluting Quantitative and Qualitive Research 4th Edition. Boston: Pearson.

Darmuki, A., Andayani, Nurkamto, J., \& Saddhono, K. (2017). Evaluating information-processing-based

learning cooperative model on speaking skill course. Journal of Language Teaching and Research, 8(1), 44-51. https://doi.org/10.17507/jltr.0801.06 Djatmika \& Pambudi, D.H. (2015). Menulis Teks Prosedur dalam Bahasa Inggris. Bandung: Pakar Raya.

Dirgeyasa, I. W. (2016). College Academic Writing: A Genre-Based Perspective. Jakarta: In Kencana.

Glenberg, A. M. (2011). How reading comprehension is embodied and why that matters. International Electronic Journal of Elementary Education, 4(1), 5-18.

Idayani, A. (2019). the Effectiveness of Digital Storytelling on Students' Speaking Ability. Lectura: Jurnal Pendidikan, 10(1), 33-46.

Kayi, H. (2006). Teaching Speaking: Activities to Promote Speaking in a Second Language. The Internet TESL Journal, XII(11), pg 1. http://www.iteslj.org

McNamara, D. S. (2007). Reading Comprehension Strategies: Theories, Interventions and Technologies. New York: Lawrence Erlbaum Associates.

Napitupulu, S., \& Kisno. (2014). Teaching English as A Foreign Language (TEFL 1). Jakarta: Halaman Moeka Publishing.

Newton, J., \& Nation, I. S. P. (2021). Teaching ESL EFL Listening and Speaking. New York: Esl \& Applied Linguistics Professional. 
Nurgiantoro, B. (2011). Penilaian dalam

Pembelajaran Bahasa dan Sastra.

Yogyakarta: BPFE.

Parse, R.R. (2001). Qualitative Inquiry: The Path of Sciencing. London: Jones and Bartlett.

Pawlak, M., \& Waniek-Klimczak, E.(2015). Issues in Teaching, Learning and Testing Speaking in a Second Language. Heidelberg: Springer.

Prihatna, R. Y., \& Him'mawan Adi Nugroho. (2015). an Analysis on Generic Structure and Language Features of Procedure. 1-7.

Sugiyono. (2016). Metode Penelitian Pendidikan: Pendekatan Kuantitatif, Kuliatatif dan R\&D (cetakan ke 23). Bandung: Alfabeta.

Ur, P. (2012). A Course in English Language Teaching. Cambridge: Cambridge University Press.

Wrench, J.S. et al. (2012). Public Speaking: Practice and Ethics. Retrieved on October 10, 2016, from http://2012books.lardbucket.org/bo oks/publicspeaking-practice-andethics/. 